\title{
Coronavirus Impact
}

When you think about the coronavirus pandemic, how worried are you about...? Are you (reversed) very worried, somewhat worried, not too worried or not at all worried?

\section{Asked in random order- sorted by \% worried}

1) Your health or the health of others in your household

worr

Total Total not worried worried

1

\begin{tabular}{ccccc}
$\begin{array}{c}\text { Very } \\
\text { worried }\end{array}$ & $\begin{array}{c}\text { Somewhat } \\
\text { worried }\end{array}$ & wot too & Not at all & Not \\
worried & Unsure & applicable \\
\hline
\end{tabular}

2) Your long-term personal

financial situation $.37 \%$

$62 \%$

$12 \%$

$25 \%$

$33 \% \quad 29 \%$

$1 \%$

3) Your current personal

financial situation. $36 \%$ $64 \%$

$8 \%$

$28 \%$

$29 \%$

$35 \%$

$0 \%$

4) The security of your job or the job of someone in your household $.27 \%$ $62 \%$ $8 \%$ $19 \%$ $20 \%$ $42 \%$ $1 \%$ $10 \%$

5) Has your household income declined since the coronavirus outbreak?

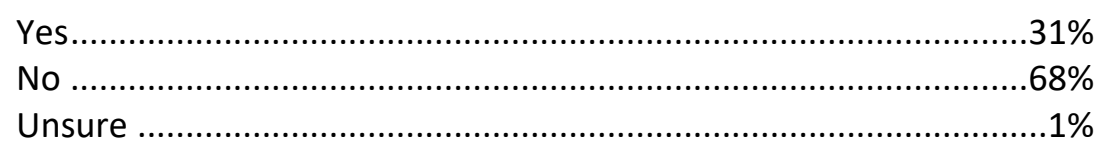

6) Since the beginning of the coronavirus outbreak in 2020, were you or anyone in your household laid off or furloughed from a job?

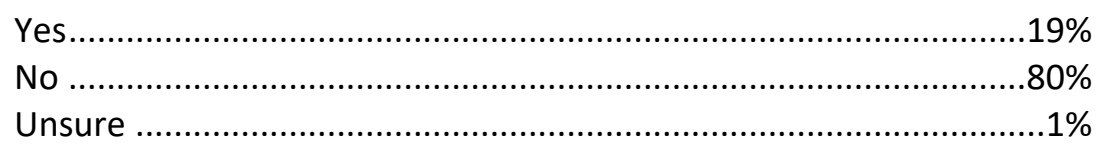

7) And have you or anyone in your household had to take a cut in pay at work due to reduced hours since the beginning of the coronavirus outbreak?

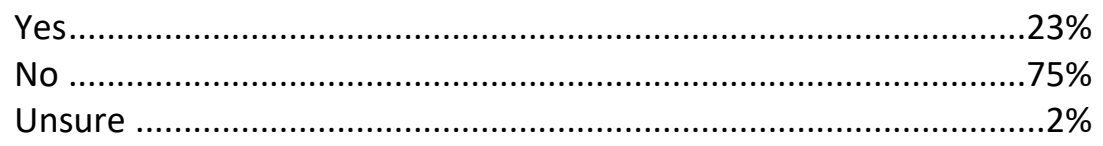

8) Thinking just about you, how would you rate your personal financial situation these days.... would you say you are in (reversed) excellent shape, good shape, fair shape, or in poor shape financially?

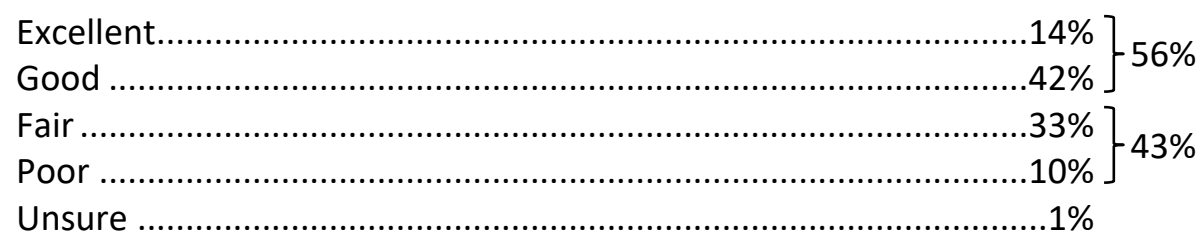


Now l'd like to hear what you think about Alaska's current economic situation...

9) How would you rate the current condition of the economy in Alaska... is it (reversed) excellent, good, only fair, or poor?

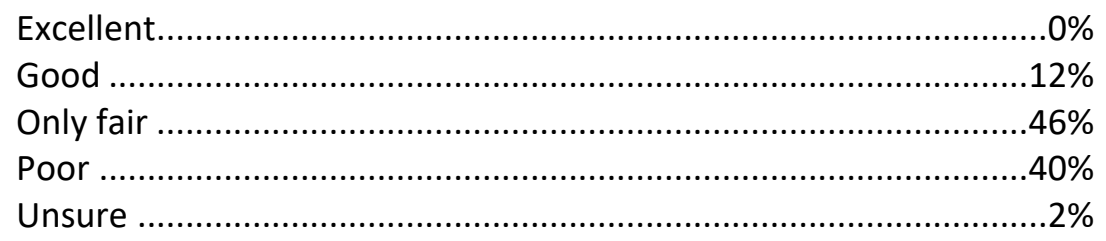

10) As you may know, Alaska is facing long-term budget challenges. Before hearing me tell you this, how much had you heard, seen or read about these budget challenges over the past 12 months... would you say (reversed) a great deal, a fair amount, some but not much, or nothing at all?

A great deal
A fair amount
Some but not much
Nothing at all
Unsure

For many years, Alaska used its oil revenues to balance the state budget and fund state services and programs. At the same time, the state used Permanent Fund earnings to issue dividend checks to all Alaska residents. As oil revenues declined, the state reduced spending on services and programs and used the state savings account to help balance its budget. Now, the state savings account is nearly depleted, and the state is using Permanent Fund earnings to help pay for services and issue dividend checks to residents. Without enough oil revenue or state savings to draw from, Alaska is considering additional cuts and new ways to raise revenue to help balance the state budget, maintain state programs and services, and continue issuing Permanent Fund Dividend checks.

11) Which statement best represents your opinion on how Alaska should balance the state budget (randomized)...

There needs to be new taxes. $.42 \%$

There needs to be cuts to state services and programs and new taxes added ........26\%

There needs to be more cuts to state services and programs ................................25\%

Unsure 
Now, l'd like you to tell me if you would support or oppose Alaska cutting any of the following state services or programs as a way to help balance the state budget. First... Next... do you support or oppose this as a way to help balance the state budget? ...and do you strongly (support/oppose) or somewhat (support/oppose) this?

\begin{tabular}{|c|c|c|c|c|c|c|c|c|}
\hline $\begin{array}{l}\text { Asked in random order- } \\
\text { sorted by net support }\end{array}$ & $\begin{array}{l}\text { Total } \\
\text { support }\end{array}$ & $\begin{array}{l}\text { Total } \\
\text { oppose }\end{array}$ & $\begin{array}{c}\text { Net } \\
\text { support }\end{array}$ & $\begin{array}{l}\text { Strongly } \\
\text { support }\end{array}$ & $\begin{array}{l}\text { Somewhat } \\
\text { support }\end{array}$ & $\begin{array}{l}\text { Somewhat } \\
\text { oppose }\end{array}$ & $\begin{array}{l}\text { Strongly } \\
\text { oppose }\end{array}$ & Unsure \\
\hline
\end{tabular}

12) Local governments depend in part on state funds to pay for services such as fire and police protection, senior centers, buses and local road maintenance, and parks and recreation. Do you support or oppose cuts to the funds the state gives to local governments?

\begin{tabular}{ll|l|lllll}
$27 \%$ & $71 \%$ & $-44 \%$ & $7 \%$ & $20 \%$ & $31 \%$ & $40 \%$ & $2 \%$ \\
\hline
\end{tabular}

13) Cuts to public safety, courts, and jails?

\begin{tabular}{ll|l|lllll}
$24 \%$ & $73 \%$ & $-49 \%$ & $8 \%$ & $16 \%$ & $29 \%$ & $44 \%$ & $3 \%$ \\
\hline
\end{tabular}

14) Cuts to public education, including $K-12$ and higher education?

\begin{tabular}{ll|l|lllll}
$21 \%$ & $77 \%$ & $-56 \%$ & $8 \%$ & $13 \%$ & $19 \%$ & $58 \%$ & $2 \%$ \\
\hline
\end{tabular}

15) Cuts to transportation and infrastructure such as state highway and road maintenance and the ferry system?

\begin{tabular}{ll|l|lllll}
$18 \%$ & $81 \%$ & $-63 \%$ & $5 \%$ & $13 \%$ & $25 \%$ & $56 \%$ & $1 \%$ \\
\hline
\end{tabular}

16) Cuts to health services for children and low-income families?

\begin{tabular}{ll|l|lllll}
$16 \%$ & $83 \%$ & $-67 \%$ & $4 \%$ & $12 \%$ & $24 \%$ & $59 \%$ & $1 \%$ \\
\hline
\end{tabular}

17) Cuts to home care services for older Alaskans or those with disabilities such as meals on wheels, personal care assistance, and transportation services?

\begin{tabular}{ll|l|lllll}
$13 \%$ & $86 \%$ & $-73 \%$ & $5 \%$ & $8 \%$ & $24 \%$ & $62 \%$ & $1 \%$ \\
\hline
\end{tabular}


Next I have a series of questions about Alaska imposing new taxes or increasing current taxes to help balance the state budget and maintain state services and programs.

18) As you may know, Alaska does not collect a state sales tax. Would you support or oppose a state sales tax of $3 \%$ on all goods, except on medicine and grocery store food, as a way for Alaska to help balance the state budget and maintain state programs and services? ...and is that strongly (support/oppose) or somewhat (support/oppose)?

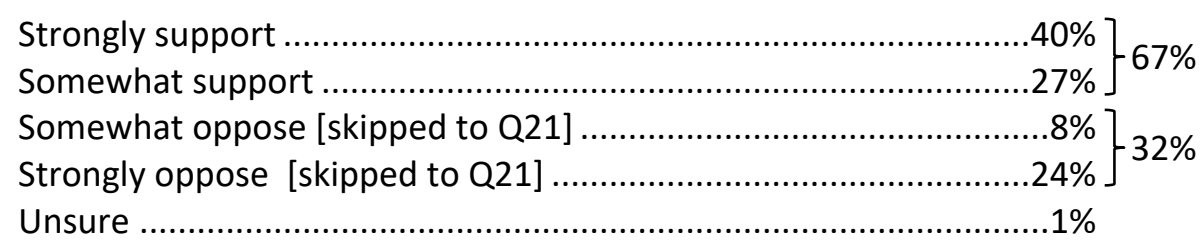

19) Many communities in Alaska already collect a local sales tax of up to $7 \%$. Would you support or oppose Alaska imposing a state sales tax of $3 \%$ if it means some communities could face a higher combined sales tax rate of as much as $10 \%$ ? ... and is that strongly (support/oppose) or somewhat (support/oppose)?

Results among 67\% who supported a sales tax on Q18

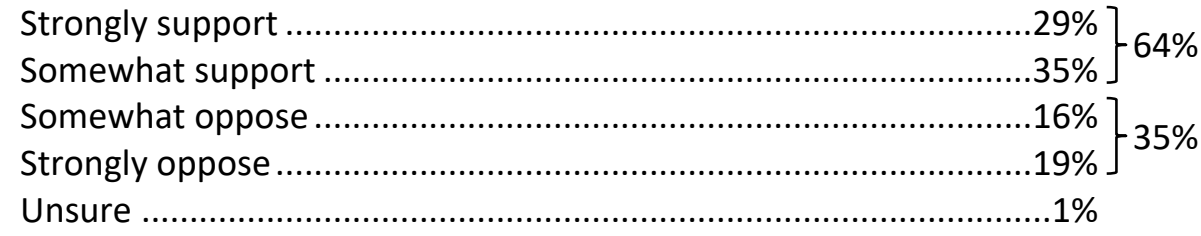

20) Some people are opposed to a state sales tax of $3 \%$ because they say it could be a burden on lowincome families because they would be spending a greater share of their earnings on taxable goods than higher income families. Considering this, would you support or oppose a state sales tax of $3 \%$ to help balance the state budget and maintain state services and programs? ...and is that strongly (support/oppose) or somewhat (support/oppose)?

Results among 67\% who supported a sales tax on Q18

Strongly support

Somewhat support

Somewhat oppose

Strongly oppose. $.43 \%]-86 \%$

Unsure .7\% $6 \% 13 \%$ $.1 \%$

21) Another approach being considered is to implement a state graduated personal income tax from $2.5 \%$ to $7 \%$ of taxable income. Under a graduated income tax system, those who earn higher incomes pay a higher tax rate than those with lower incomes. Would you support or oppose Alaska implementing a graduated income tax system as a way to help balance the state budget and maintain state services and programs? ...and is that strongly (support/oppose) or somewhat (support/oppose)?

\begin{tabular}{|c|c|}
\hline 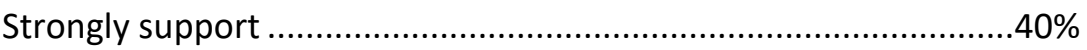 & \\
\hline Somewhat support ................. & \\
\hline 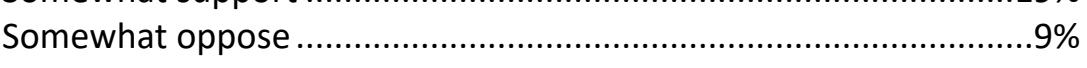 & \\
\hline Strongly oppose & \\
\hline Unsure & \\
\hline
\end{tabular}


22) Would you support or oppose increasing taxes on oil and gas companies in Alaska as a way to help balance the state budget and maintain state services and programs? ...and is that strongly (support/oppose) or somewhat (support/oppose)?

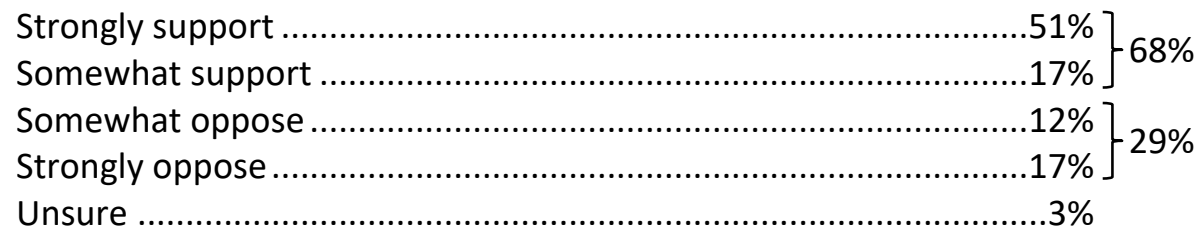

\section{Permanent Fund}

23) How important is the Alaska Permanent Fund Dividend Check to you? Would you say very important, somewhat important, not too important, or not important at all?

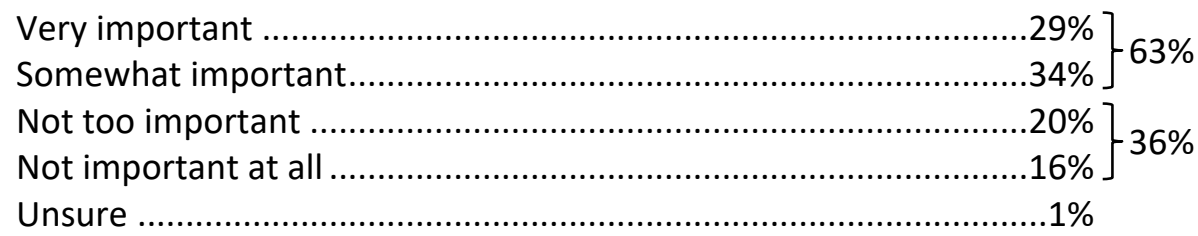

24) Would you support or oppose Alaska capping the amount residents receive in their Permanent Fund Dividend checks each year as a way to help balance the state budget and maintain state services and programs? ...and is that strongly (support/oppose) or somewhat (support/oppose)?

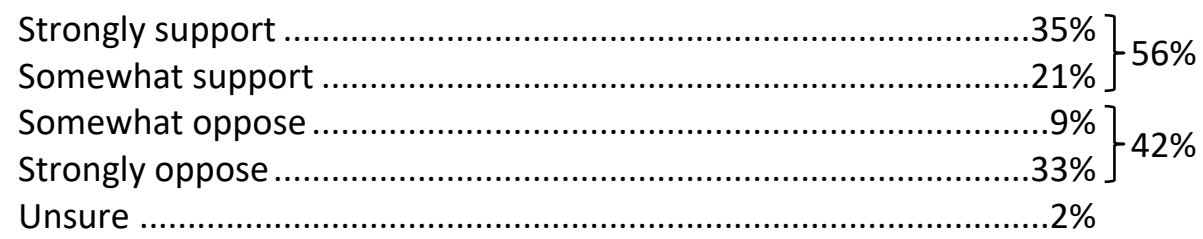

25) Would you support or oppose ending the Permanent Fund dividend checks if it meant that Alaska would not need to impose a state sales or personal income tax to balance the state budget and maintain state services and programs? ... and is that strongly (support/oppose) or somewhat (support/oppose)?

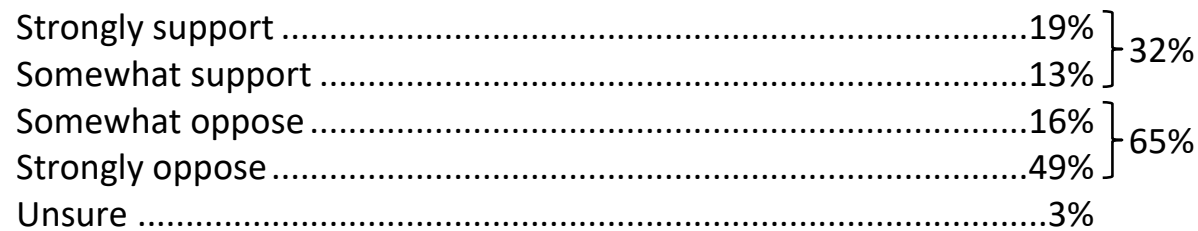

26) Now l'd like you to consider the various proposals we've discussed for balancing the state budget and maintaining state services and programs. I'm going to read a short list of these proposals, then please rank them in order of what you support the most, to what you support the least. First... Next... Which do you support the most? And what would be next on your list...

Increasing taxes on oil and gas companies.....................37\%

A state sales tax.

A state personal income tax

Capping the Permanent Fund Dividend amount

Cuts to state spending on programs and services

\begin{tabular}{c} 
Last Choice \\
\hline $10 \%$ \\
$7 \%$ \\
$18 \%$ \\
$18 \%$ \\
$47 \%$
\end{tabular}

Mean Score 3.77

3.18

3.09

2.98

2.36

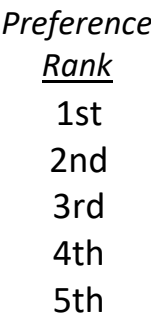


34) Thinking about who lives in your household, do you currently...?

Have any children age 18 and under living with you? ................................ 7\% $\quad 93 \%$

Have any children age 19 and older living with you? ................................ 11\% $\quad 89 \%$

Have any children away at college or living on their own? ......................... $48 \% \quad 52 \%$

Have a parent or adult relative living with you? ........................................ 4\% $\quad 96 \%$

Have any grandchildren or other related children living with you? ...............6\% $\quad 94 \%$

[if necessary: such as nieces or nephews]

35) Are you currently a family caregiver providing unpaid care to an adult loved one - such as assisting with personal needs like bathing, meals, transportation or medical care?

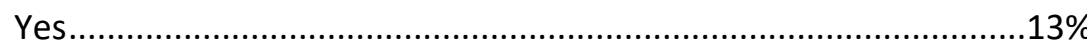

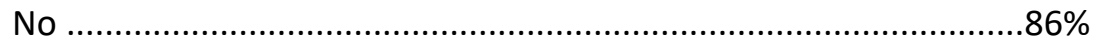

Not provided/Unsure................................................................1\%

36) What is the highest level of education that you completed?

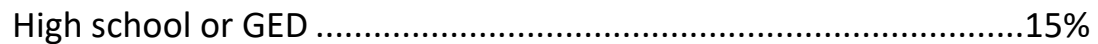

Some college or technical school ....................................................36\%

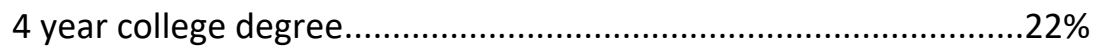

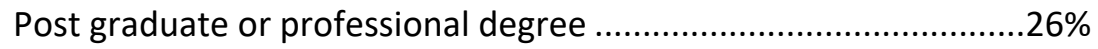

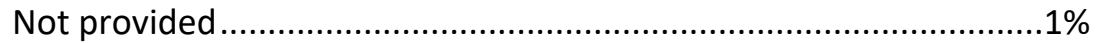

37) Which of the following best describes your current employment status? Are you...?

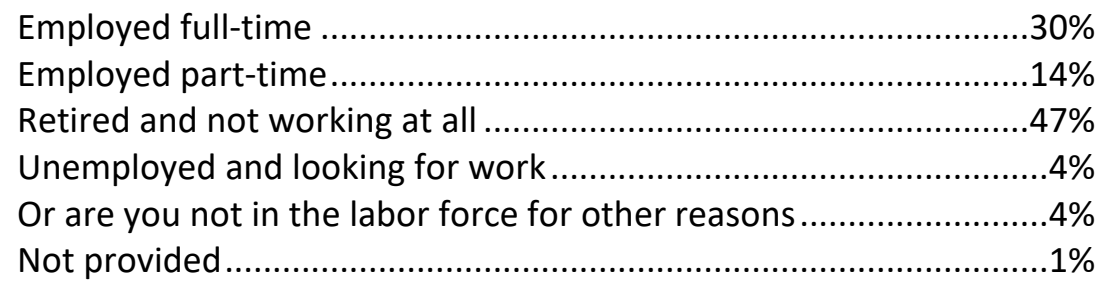

38) Are you of Hispanic, Spanish, or Latino origin or descent?

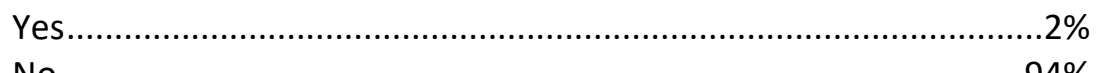

Not provided/Unsure............................................................ $4 \%$

39) What is your race or ethnic background?

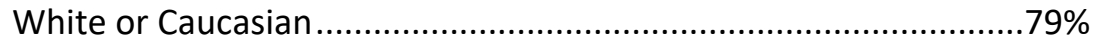

Alaska Native or American Indian .....................................................8\%

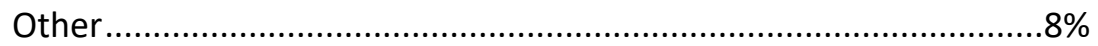

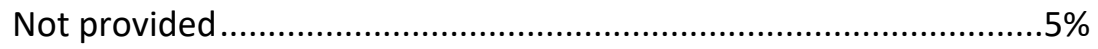


40) How closely would you say you follow local news and politics in Alaska...

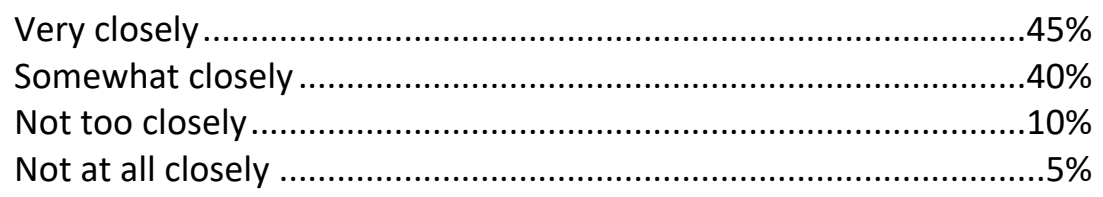

41) If you are registered to vote, did you register as a (randomized) Democrat, Republican, Non-Partisan, Undeclared, or something else?

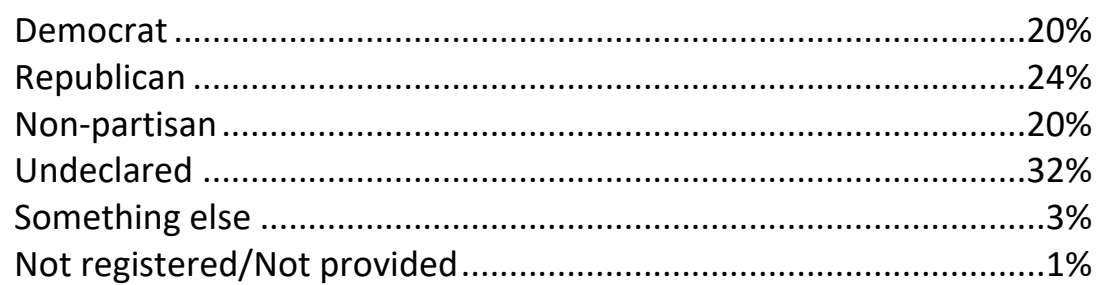

42) How would you characterize your political views?

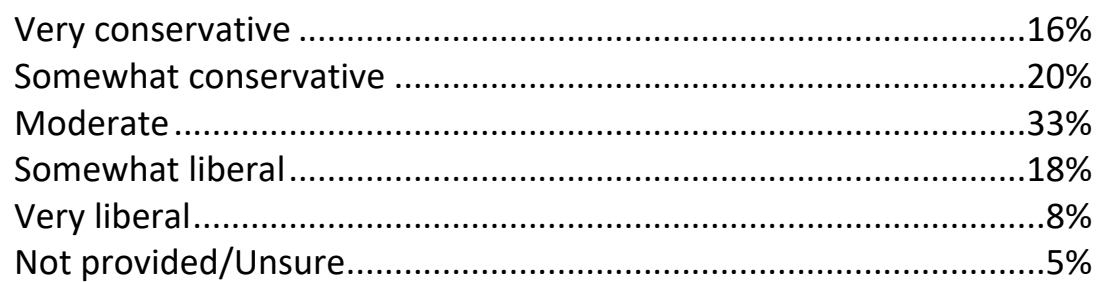

43) We realize income is a private matter and so rather than ask you anything specific about your income, could you please tell me in which of the following broad ranges your total annual household income falls? Please stop me when I reach yours...

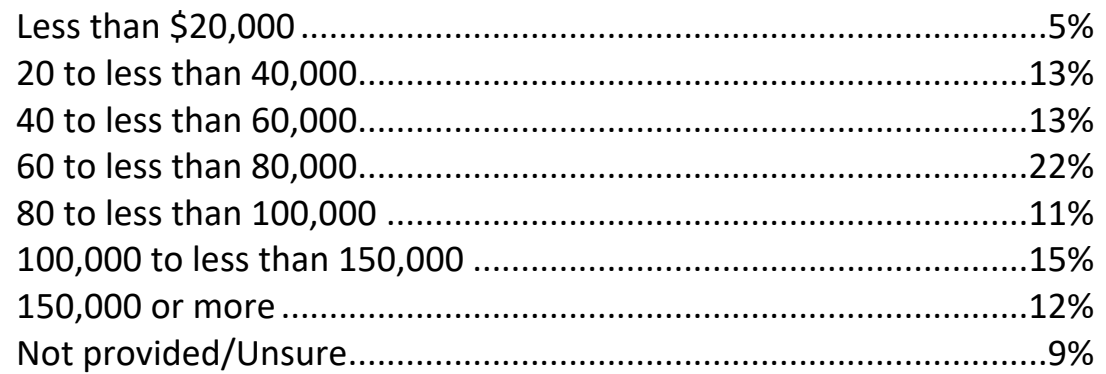

\section{Methodology}

This research was conducted by Dittman Research for AARP. During the period March 3-14, 2021, 428 Alaskan residents, age 50 and older, who are AARP members or someone in their household is, were interviewed via live interviewer telephone survey. Interviews averaged 17 minutes in length. Approximately half of respondents (49\%) were interviewed on their cell phone. The survey featured a probability sample and has a margin of error of $+/-4.7 \%$ at a $95 \%$ confidence interval. Interviews were fielded based on the geographic distribution of Alaskans age $50+$, with the exception of the rural oversample. Region-level interview quotas by age and gender were used to ensure a representative sample of Alaskans was collected. The data required minimal weighting to bring the survey sample into alignment with the actual demographic characteristics of Alaskans age 50+. 